\title{
Need Analysis: Textbook Development of Modern Indonesian Literary History (Poem in East Java Province, Indonesia)
}

\author{
${ }^{1}$ Sutrimah, ${ }^{2}$ Retno Winarni, ${ }^{3}$ Nugraheni Eko Wardani, ${ }^{4}$ Ngadiso \\ ${ }^{1}$ sutrimahyusuf@yahoo.com, ${ }^{2}$ winarniuns@yahoo.com, ${ }^{3}$ nugraheniekowardani_99@yahoo.co.id, \\ ${ }^{4}$ ngadisodok@yahoo.com \\ 1,2,3,4 Sebelas Maret University Central Java, Indonesia
}

\begin{abstract}
The existing textbook on Literary History has weaknesses; first, the materials are old, second, the availability is very limited; third, the materials inside the textbook are in the national context; fourth, no textbook discusses about poems in East Java. This research aimed at describing: (1) the conditions of historical textbook of modern Indonesian literature (poem in East Java Province in Indonesia), (2) the needs analysis on the development of that textbook. It is exploratory research with descriptive-qualitative design. The data were obtained through interview and observation to some lecturers and students of three private universities in East Java. The results of research bring to the need of a textbook with poems in East Java materials. By this book, the students will love literature and close them to the recent literary works.
\end{abstract}

Keywords: Textbook; Indonesian Literary History; Poem in East Java.

\section{Introduction}

Indonesian literary history discusses Indonesian literature since its early until recent development. Besides, literary history also talks about literati, literature, and period. The history of Indonesian literature undergoes many renewals in terms of periodization. Many historians divide the periodization of Indonesian literature into some periods with different terms. Basically, various terms they used refer to the same meaning but they have different reasons for giving a specific name.

In some universities in Indonesia, the curriculum of Indonesian Education and Literature Department obliges all students to take the course of literary history as it is the basic course in literary science. In the context of literary science, literary history together with literary theory and literary critic becomes the branches of literary science Wellek \& Warren[1].

As the basic course, literary history belongs to a pivotal course to students. Therefore, lecturers as the teaching and learning organizer are obliged to deliver the materials through a textbook. One of teaching media which is very meaningful and supportive for the learning process in class is a textbook. A complete and systematical textbook can create effective and efficient teaching and learning process. In other words, the quality of textbook is one of the decisive factors to reach the goal of teaching. Therefore, a textbook is an essential element which must be concerned with teaching and learning process.

The recent textbooks used as the reference for literary history are the ones written by some experts. Those books become the references or standards in teaching literary history such as the books entitled Sastra Baru Indonesia I written by A. Teeuw, Sastra Indonesia Modern II written by A. Teeuw, Sejarah Sastra Indonesia Modern, and Kitab Sejarah Sastra Indonesia written by Yant Mudjianto and Amir Fuadi. Those books discuss the history of modern Indonesian literary in national or broad context. Therefore, a textbook of Modern 
Indonesian Literary History (MILH) with specific material and a huge benefit to literary history course is required. Specific materials will be more interesting if they are connected to the students' conditions. Thus, developing specific material in this context is very important as the existing textbooks have broad coverage and talk about all literary works including prose (short story and novel), poem, and drama in the national scale.

Considering the importance of a textbook and the content of the existing textbooks, this research formulated discussed about two main problems as follows: 1) how were the conditions of the existing textbooks of MILH (poem in East Java Province) used by private universities in Bojonegoro Regency, 2) what were the needs analyses for developing a textbook regarding MILH.

\section{Related Works/Literature Review}

Tarigan (1986:67) states that a textbook is the record of rational thinking which arranged in the form of a book to reach certain instructional objectives of teaching and learning. A textbook need to present sequential thinking arrangement with which the readers can understand its content. The Regulation of National Education Minister No. 2/2008 article 1 verse 3 stipulates that a textbook refers to a compulsory reference book used by every educational institution or higher education containing learning materials for improving religious faith, piety, honorable attitude, personality, science and knowledge acquisition, sensitiveness, esthetic ability, kinesthetic ability, and health which composed based on the national standard of education.

Furthermore, a textbook is a book which can enrich the existing textbook already used at schools Trihartati[2]. According to Rifai[3], a textbook means a book used for learning and deepening a subject of knowledge, science, technology, and art containing the principles of scientific works and related literary.

Thus, a textbook can be defined as a book of certain subject or course which is standardized and arranged by an expert(s) in a certain field for achieving instructional objectives as well as supported by appropriate and understandable teaching media.

Tarigan \& Tarigan[4], state that the characteristics of a good textbook are as follows. (1) It contains only one subject; (2) It contains learning materials which are suitable for the current curriculum; (3) It is written by the experts in its field; (4) The learning materials are written systematically; (5) The learning materials are arranged based on the learners' situation and condition in order to make them easily used and understood by the learners; and (6) It can support the teaching and learning process.

The textbook is pivotal to support teaching and learning process as many experts have investigated. Dealing with this statement, Hutchinson \& Torres in Litz[5], state that:

"The textbook is an almost universal element of [English language] teaching. Millions of copies are sold every year, and numerous aid projects have been set up to produce them in [various] countries...No teaching-learning situation, it seems, is complete until it has its relevant textbook. “"

Besides, there are also four reasons why a teacher needs to use textbook in teaching and learning process, i.e. (1) a great deal of the material, although specially designed for this group, was very suitable for their needs, (2) the textbooks made it possible for the group to look ahead to what we were going to do or to look back at what we had done, (3) the textbooks provided materials which were well-presented, which could be replaced by me or by someone else only at great cost in terms both of money and of my own time, (4) the textbooks allowed me to adapt and improvise while I was a teaching (O’Neill,[6]. 
Literature is a term from Sanskrit language shastra which means "a text with instruction or principle". In Indonesian term, this word shastra is mainly used to refer literature or a kind of writing which has certain meaning or beauty. However, literature can be used for appointing at any kind of writing, whether beautiful or not. Literature can be distinguished into written and oral literature. In this case, literature is not related to writing but with language which is used for expressing experience or thought. The word "modern" in the term of Modern Indonesian Literature refers to how intensive the west writers influence the development and growth of Indonesian literature. Indonesian literature goes to the used language medium namely Indonesian language in which content of writing reflects the attitude and character of Indonesian people in handling problems.

The history of literature learns about the development of the literature of certain community or nation. In the context of Indonesia, literary history studies about the development of national (Indonesian) literature. Through studying the history of literature students of higher education can understand kinds of literary works which had ever been produced by the writers completed with their problems discussed inside.

Wellek and Warren[1] define that the reconstruction of writer's meaning is the core of research which demands the ability of imagination and empathy about past time or a passion of past time. Therefore, learning the history of literature requires the deep involvement in past periods so that someone will feel about the past period. In short, literary works reflect the picture or description of condition in a certain period.

Kennedy[7] states that a poem is a rhythmic word composition that expresses a behavior, and is compiled to make somebody else amazed and amused and elicits an emotional response. This is in line with Waluyo[8], who state that a poem is a form of literature that expresses the thoughts and feelings of poets imaginatively and is compiled by concentrating all the power of language by concentrating the physical structure and inner structure.

Furthermore, Laurence Perrine[9] states that the meaning of a poem is as follows.

"Poetry is as universal as language. The most primitive people have used it, and the most civilized have cultivated it. In all ages and in all countries, poetry conditions of people, by soldiers' statesmen, lawyer, farmers, doctors, scientists, clergymen, philosophers, king, and queens. In all ages, it has been to children. Because it has given pleasure. People have read it or listened to it or recited it because they liked it because it gave them enjoyment".

Reeves[10] states that A poem is not a bird`s song, any more than it is a rose, but if its not something of this quality of self-sufficiency, it is not a true poem and might as well have been presented as prose". Sastri[11] states that Imagination is essentially vital in the sense that it informs and animates other existences. The objects are objects only for the imagination because it is primary imagination that creates for us the world of objects.

A poem is also often accompanied by imagination because an imagination is an experience in imagining a deliberate/conscious act of things in the real world when the real object is not in place.

"In imagining experience as an intentional act of consciousness, when objects are not present or when we imagine things that do not refer to any real objects in the world, the above discussion centers on the idea of double intentionality. This is mostly the case of images in poetry", Zalipour[12].

Boulton[13], mentions the poem-forming elements consist of the outer element and the inner element as in the quotation below: 
"The physical form is the appearance on paper, and much more important, the sound of poetry it may be either the sound when poetry is read to us, or the sound we hear mentally when we read it to ourselves.it includes rhythm, rhyme, intonation and various kinds of echo and repetition. The mental form might be described as content in the usual sense of the word when applied to literature: it includes, grammatical structure, logical sequence, the pattern of associations, the use of a dominant image, the pattern of image and emotion. all these things combine to give a good poem its power over our imagination".

The poem is part of literary works in which the figure of the poet can be measured from his/her poem. The famous poet who was born in certain event period will last longer if he/she is not supported by the marvelous poem. The persona of a poet is assessed from how great and how far his/her poem can survive. People as the connoisseur of the poem have rights to give an assessment to literary works of a poet. In other words, a poet must exist through the resulted poems so that he/she can get a special place to many people.

There are five best-poets in East Java Province i.e. Mardi Luhung, Indra Tjahyadi, Muttaqien, F. Aziz Manna, and M.Fauzi. These five poets are categorized as the best poets due to the strengths of their poems, although they did not involve in literary events in East Java.

In the beginning of his emergence in 1990, Mardi Luhung has surprised Indonesia by his poems. He has created an esthetical pattern which is nice to read but wild in interpretation. Reading Mardi's poems is as comfortable as reading the poems of D. Zawawi Imron. However, they are different. Mardi accommodates many things, images, and even suggestions. His poems are easy to read but difficult to interpret. On the contrary, Zawawi's poems are easy to read and interpret. In this case, Mardi's poems have dark character.

Indra Tjahyadi is an Indonesian poet who likes fantasy. The way how he plays fantasy cannot be equalized with other poets in 1970s or 1980s eras. The poems of Indra can only be equalized with those of Acep Zamzam Noor. Based on the reality of thoughts, Indra tjahyadi's poems wander to realities which can only be imagined but difficult to find in the actual realities. The results are imaginative realities. It is fortunate that Indra has universal sensitivity. His wildness can still be read by his readers. In addition, Indra often plays the rhythm of thoughts so that the dynamic flow can be created. The other Indra's strength is that he likes to play the techniques of poems. In his anthology, he presented a creole technique of Surabaya. He mixed oral aspect of low-level community in Surabaya with the oral aspect of Chinese people.

A. Muttaqien came suddenly without speaking much. His poem pilfered one full-page of national mass media. Unlike Indra who is very productive, Muttaqien can be categorized as a poet with low production. However, his poems never got a rejection from mass media. The strength of this poem is on his diligence in keeping metaphor. Although he puts metaphor of his poems in a cool way, no explosion inside, his poems are neat and frozen. He is meticulous to make a pair of sounds in every row. Yet, when the word series is lyrical, the readers will not find their implicit meanings. The readers will only get association, metaphoric awareness, and the rest is darkness.

Unlike F. Aziz's poems, when Indonesian poets are very fond of lyric, Azis chooses the other way called violent way. In the lyrical poems, every word is controlled tightly, but the words in Aziz's poems run freely. His words sometimes jump, crash, and even weaken each other. His words spurt shaping complicated poem area.

Poetic poems of Azis are supported by accommodated theme, specifically Surabaya City. Azis' poem is analogous to morning Sunday market along the road of Pahlawan. Many 
merchants shout to get buyer's attention, people go back and forth in the crowd, traffic congestion, and fast transaction of a city. Azis'poems accommodate lifestyle of Surabaya metropolitan city which is stuffy and crowded. His poems give transparent esthetical pattern just like Surabaya people who are open-minded but sometimes say profanity.

Madura, a small island in East Java Province, has many dozens of qualified poets. One of which is M. Fauzi who combined esthetical pattern owned by the previous poets with the newest. Fauzi, without any burden, put the thought of philosopher, Derrida, into his poems. Not only thought but also philosophical terms can be found in Fauzi's poems. He is so religious that make him use Arabic terms from Al Qur-an into his poems.

Fauzi's poems direct his readers to go through wide knowledge. The readers are challenged to find references which sometimes refer to the insights of philosophy, religion, and even things in the supermarket. This kind of technique embedded Fauzi's poems with Afrizal's. However, Fauzi has a typical characteristic which afrizal does not. Fauzi is closed to yellow holy book. Moreover, the tendency becomes the major generator of Fauzi's poems, while Afrizal generates his poems based on the social problems and the divided anthropocentrism philosophy.

Out of those five poets, there are some more potential poets such as Tengsoe Tjahjono, a lecturer of Surabaya State University. Although he is not so productive, he keeps production intensity. As a lecturer, he understands and realizes creative process. Unfortunately, Tengsoe never creates awesome poems. He just can produce good poems but not outstanding ones. The similar case also happens to Mashuri, Tjahjono Widarmanto, and Tjahjono Widijanto. These poets have same quality with young poets at Gapus Teatre and Rabo Sore Community. All the four poets are saved by time and esthetical awareness. Within 10-20 years, all of them consistently wrote poems. They keep their standardized esthetics. Unfortunately, they cannot create awesome esthetical poems. If there were one or two explorative poems, those numbers went down by the other numerous mainstreams.

There are three poets who are eligible to mention. They are W. Haryanto, S. Yoga, and Denny Tri arryanti. They have ever got an exact esthetical moment with their sensational poems. They create metaphors which are arrogant but deep. The series of diction are evocative to interpretation or called hermeneutic.

Unfortunately, during the last five years, these three poets are come up but then get drowning. They do not show passion in playing words. There are two choices which can be taken by them, running from past time or go back to the past time. The former choice means building a new esthetical moment which can be used as the fundamental of a creative process. The second choice means going back to the traces of old creative process which bring them to the standard of creating esthetics. Considering the recent development, these three poets seem to select the former choice. They are honest about the recent condition and build the esthetical moment.

The other poets are Akhudiat and D Zawawi Imron. Their ages should have been over as they did not give new exploration. In fact, they sometimes create poems in which quality cannot be underestimated. Both are poets with exclusive class. Whatever poems they create, the public will trust in their creations.

Overall, based on those mapping, poetry in East Java Province, Indonesia does not depend on the rowdy contexts of literary events. Poetry is still poetry which stands on poem text. Literary figures who born from certain moment but are not supported by qualified poems will be like a ceramic statue. It seems strong and shiny, but when it is knocked, it will sound like the empty content. If it falls down, it will be broken. In other words, poetry is inherent within a text. 


\section{Material \& Methodology}

This research belongs to descriptive-qualitative design. This exploratory study becomes the first step of Research and Development as the final goal of this research is developing a textbook on Modern Indonesian Literary History (MILH), to be exact in Poem at East Java Province, Indonesia. It focuses on the information gathering related to the actual condition of the textbook with which then used as the reference. The qualitative emphasizes on the notes which describe the real situation as close as the original form Sutopo[14], The data sources consist of informants including the heads of department, lecturers, and students; as well as observation results toward the existing situation. The data collection techniques were interview and observation. The analysis model employed interactive model proposed by Miles and Huberman[15] which comprises from three ways of activities i.e. 1) data reduction, 2) data presentation, 3) conclusion drawing/verification. In the exploration phase, the first thing needs to be done is reviewing related literature; the second is going to field to investigate the model existence or quality and do needs analysis, the last is making product specification.

The data in the exploration phase were collected in six months, from July 2016 to December 2016. The data were obtained from three private universities in three cities which own Indonesian Language and Literature Department. They are IKIP PGRI Bojonegoro in Bojonegoro, PGRI Ronggolawe University in Tuban, and Darul Ulum University in Lamongan. This exploration phase was carried out by investigating the teaching and learning process during Literary History $(\mathrm{LH})$ course. It aimed at getting the comprehensive condition on the conduct of this course and knowing the students and lecturers' needs on the textbook of LH course. This phase obtained the information related to the strengths and weaknesses of the existing teaching and learning process of $\mathrm{LH}$ which then becomes the reference for developing a textbook on MILH.

\section{Results and Discussion}

\subsection{The condition of the existing textbook on Literary History course \\ 4.1.1. Curriculum of Indonesian Language and Literature Department}

The curriculum of Indonesian Language and Literature Department has been formulated based on the Constitution No. 20/2003 regarding the National Education System, Government Regulation No.60/1999 on Higher Education, Minister Decree of National Education of the Republic of Indonesia No. 232/2000 on The Principles of Curriculum Arrangement and Assessment on the Students' Outcomes, and Minister Decree of National Education No. 045/U/2002 on The Core Curriculum of Higher Education.

Based on the analysis of course distribution, the Indonesian Language and Literature Department allocates 148-158 credits for its students to finish their undergraduate program. Out of these credits, 16 credits are about the literary course, to be exact in the courses of Literary History, Literary Theory, Literary Criticism, Fiction Prose Appreciation, poem appreciation, and Drama Appreciation. Thus, there has been an equilibrium in the credits portion of literary courses with the whole credits. It means that there has been equilibrium for lecturers to develop their competences in literature with other competences.

The results of interviewing the lecturers of three private universities being studied showed that the total credits of department courses with those of literary courses are ideal. In short, there have been considerations on the portion of literature, linguistics, teaching, and personal development fields. 


\subsubsection{Profile of Lecturer}

The total lecturers at Indonesian Language and Literature Department have fulfilled the requirement. The proportion between lecturer and students was below 45 (as required by General Directorate of Higher Education). In other words, it was categorized very good. There has been a specification of lecturers who teach literary courses based on the educational background and their intensity in teaching literature.

Table 1 shows the equilibrium of total students and lecturers at the Department of Indonesian Language and Literature.

\begin{tabular}{lccccccc}
\hline \multicolumn{1}{c}{$\begin{array}{c}\text { Private } \\
\text { Universities }\end{array}$} & $\begin{array}{c}\text { Total } \\
\text { Students }\end{array}$ & $\begin{array}{c}\text { Lecturers' } \\
\text { Education }\end{array}$ & Total & Ratio & $\begin{array}{c}\text { Total } \\
\text { Lecturers } \\
\text { of } \\
\text { Literature }\end{array}$ \\
\cline { 2 - 8 } & 296 & - & 10 & - & 10 & $1: 29$ & 3 \\
\hline $\begin{array}{l}\text { IKIP PGRI } \\
\text { Bojonegoro }\end{array}$ & 334 & 3 & 13 & 7 & 23 & $1: 14$ & 4 \\
\hline $\begin{array}{l}\text { Darul Ulum } \\
\text { University, } \\
\text { Lamongan }\end{array}$ & & & & & & & \\
\hline $\begin{array}{l}\text { PGRI Ronggolawe } \\
\text { University, Tuban }\end{array}$ & 240 & - & 10 & 1 & 11 & $1: 21$ & 3 \\
\hline \multicolumn{1}{c}{ Total } & 870 & 3 & 33 & 8 & 44 & & 10 \\
\hline
\end{tabular}

Table 1. Students and lecturers equilibrium at Department of Indonesian Language and Literature in three universities

Based on the interview and observation results, the lecturers' competences are good and appropriate for the literature course. In terms of educational background, all lecturers have supported education for each course they teach. The lecturers who teach literature course graduated from the best universities. Some students being interviewed also stated that when the lecturers teach literature course, their explanation is good but difficult to understand. The lecturers sometimes break down the learning activities from the beginning to the end of the course. Students were obliged to write a book. The lecturers open the teaching and learning process by giving questions and answer session at every meeting so that students feel free to ask about literature.

\subsubsection{Profile of Student}

At the odd semester of the academic year 2016/2017, the total active students at Department of Indonesian Language and Literature in three private universities were 870. In detail, there were 296 students of IKIP PGRI Bojonegoro, 240 students of PGRI Ronggolawe Tuban University, and 334 students of Islamic University of Darul Ulum, Lamongan.

Based on the interview results, many students do not like literature course because they argued that literature is not important. Most of the students want to be teachers so 
that they think that literature is not essential. If there are students who like literature, actually they like it since they were in school. They taught that learning literature must be supported by the love of literature. Overall, the students think that literature is difficult, unimportant, and not suitable for their dream, to be a teacher.

\subsubsection{The Teaching Activity during Literary History Course}

There are 14 meetings for Literature History course. The materials are about the history of national literature in terms of the poets, literary works, period, and literary development from period to period. The materials on the poems in East Java Province were not delivered. Consequently, the students have low knowledge of the poems of East Java. However, the teaching of Literature History is very important for three reasons. First, poems belong to literary works which are easy to find and enjoyed by readers. Second, the teaching of Literary History by accommodating poems of East Java will be able to grow the sense of local poems. Third, this course introduces to young generation about the local literary works and teaches the literary history in Indonesia since its early, growth, and recent development.

One of the lecturers said that to grow the student's sense of love to literature was very difficult although they have been given a forum to discuss such as KOSTELA (Komunitas Pecinta Sastra Lamongan or Literature Lover Community in Lamongan) and HMJ (Himpunan Mahasiswa Jurusan or Student Association of Study Program). These forums often undergo activity of literature, but the results were underachievement. Lecturers also instructed their students to make a book as the final assignment. Lecturers gave students assignment in which results were then compiled to be a book. This assignment is a part of efforts in growing the sense of love to literature. The book contains folklores from each students' regions.

The result of observation to teaching and learning process of literary history course reported two findings. First, the referenced textbook was only owned by the lecturers. They employed expository method in delivering the teaching materials. Second, almost all lecturers taught literary history course mechanically, starting from the explanation of the history of Indonesian literature, poets and their periods, and literary works. The last material was on the poets from period 2000s, no specific material on poems in East Java.

\subsubsection{The textbook Used for Literary History Course}

One of lecturer reported that the textbooks used as the reference entitled Ikhtisar Sejarah Sastra, Kapankah Kesusateraan Indonesia Lahir, Sari Kesusasteraan Indonesia, and other relevant textbooks. The materials in those books were selected based on the materials being taught. The students are free to choose a textbook. No textbook is much about poems in East Java. Few books discuss deeply and only focus on the period 2000s. In other words, a textbook with poems of East Java will be helpful for teaching and learning process of Literary History.

The other lecturer said that the materials of Literary History contain poem material but not poems in East Java. So many materials want to be explained but the time is very limited. Thus, it is very important to have a textbook on poems of East Java because it can broaden student's knowledge and develop culture and tradition to modern community. The limited availability of the existing textbook has aroused to the emergence of a 
textbook on poems of East Java. Moreover, the existing textbooks are old materials, so no new materials are available.

There are some activities of literature such as the award of East Java literature held by The Council of Art in Lamongan and school events on literature. All of these prove the intensity on literature world.

\subsection{The Needs Analysis of Students and Lecturers on the Literary History Textbook}

The development of Modern Indonesian Literary History is very important for some reasons: first, to introduce the students about poems in East Java; second, to build the sense of love on the history of literature. A textbook on this topic can serve as a helpful teaching medium. This textbook is expected to motivate students to learn and love the history of literature. The students must have good academic achievement and motivation toward literary history. They must not underestimate this course.

\section{Conclusion}

Based on the findings and discussion, some conclusions can be drawn: first, the conditions of the existing textbooks are old materials, limited availability, demotivate students to learn, and lack of poems on East Java. Therefore, a textbook on Modern Indonesian Literary History is very important for some reasons: first, it can arouse student's motivation for learning the history of literature; second, it can grow and deepen the sense of love to literary history.

\section{ACKNOWLEDGEMENT}

This paper is partly funded by Indonesian Ministry of Research, Technology and Higher Education on Doctoral Dissertation Research Scheme with Contract Number: 077/SP2H/K2/KM/2017 on May 9, 2017. We would thank IKIP PGRI Bojonegoro, Darul Ulum University Lamongan, and PGRI Ronggolawe University Tuban, for providing the access and ethical clearance for the research participants.

\section{References}

[1] W. Rene, Wellek and Austin, Theory of Literature. New York: Harcourt\& Word, 1968.

[2] W. Triharti, Peran Pusat Perbukuan dalam Penulisan dan Penerbitan Buku Akademik. LPP UNS, 2010.

[3] M. Rifai, Peningkatan Motivasi Penulisan Perguruan Tinggi yang disampaikan dalam Lokakarya Penulisan dan Penerbitan Buku di Lingkungan Universitas Sebelas Maret. 2010.

[4] H. G. dan D. T. Tarigan, Telaah Buku Teks Bahasa Indonesia. Bandung: Angkasa, 1986.

[5] L. David R.A, Textbook Evaluation and ELT Management: A south korean case study. Asean EFL Jornal, 2012.

[6] O. Robert, "Why use textbooks," ELT J., vol. 3, no. 2, 1982. 
[7] K. X.L, An Introduction to Poetry. Boston: Little, Bronw and Company.

[8] H. J. Waluyo, Pengkajian dan Apresiasi Puisi. Salatiga: Widya Sari Press, 2010.

[9] P. Laurence, Sound and Sense: An Introduction to Poetry. New York: State University of New York Press, 1974.

[10] R. James, Teaching Poetry. London: Heinemann, 1972.

[11] S. Subagio, Sekilas Soal Sastra dan Budaya. Jakarta: Balai Pustaka, 1999.

[12] A. Zalipour, "Phenomenological Studies of Imagination in Poetry: An Introduction," Southeast Asian J. English Lang. Stud., vol. 16, no. 1, pp. 100-119, 2010.

[13] B. Marjorie, Anatomy of Poetry. New York: Holt, Reinhart \& Winston, 1993.

[14] H. Sutopo, Metodologi Penelitian Kualitatif. Surakarta: UNS Press, 2002.

[15] H. B. Mathew, Miles and Michael, Analisis Data Kualitatif Buku Sumber tentang Metode-Metode Baru. Jakarta: UIP, 1992. 